\title{
A Protestant Verdict on the Jesuit Missionary Approach in Africa: David Livingstone and Memories of the Early Jesuit Presence in South Central Africa
}

\author{
Festo Mkenda, s.J.
}

David Livingstone $\left({ }^{1813-73)}\right.$ is a larger-than-life figure in the history of Christian missions in Africa. However, reaching Africa for the first time in 1841, he is far from being the continent's first missionary. His first contact with Africa was mediated by Robert Moffat (1795-1883), a Scottish Congregationalist missionary, who had already settled at Kuruman in today's South Africa in 1817, and who would later become Livingstone's father-in-law. More importantly, Livingstone himself noticed the marks left behind by Jesuit missionaries who had evangelized in the lands he was visiting before departing from the region close to a century before his own arrival. In his writings, Livingstone made mostly anecdotal references to these Jesuits, yet he believed he had observed enough of their legacy in southern Africa to enable him to comment on their missionary methods and achievements. While he praised the way the Jesuits financed their missions and the success they had in their educational work among native Africans, he was scathing about their failure to impart durable faith in their African converts, a failure he attributed to the Jesuits' Catholic background and their associations with the slave-dealing Portuguese authorities.

Livingstone's assessment of Jesuit success and failure in south central Africa calls for a deeper analysis. His verdict is best understood within the context of his own mission to Africa, more specifically as a Protestant evangelizer, an anti-slavery campaigner, and a pioneer of a commercial empire. ${ }^{1}$ Moreover, his experience as a medical doctor, a British consul, and an explorer also contributed to determining what he admired or criticized the Jesuits for. ProtestantCatholic competition, often marked by less than civilized language, is an essential element of the nineteenth-century Christian evangelization of the

1 See J.P.R. [John Peter Richard] Wallis, ed., The Zambezi Expedition of David Livingstone 1858-1863, 2 vols. (London: Chatto \& Windus, 1956), 1: xi. 
African interior. This so-called third-wave of evangelization was taking place at a time when notions of ecumenism and a desire for unity among different Christian denominations were still in their infancy. Statements by someone like Livingstone, who had such a towering influence across denominational boundaries, help us understand not only his own opinion at the time but also the ways in which African Christianity can be viewed today.

\section{Protestants and Catholics in Nineteenth-Century Africa}

During the first half of the nineteenth century, most of the African interior was an open missionary field. Between 1818 and 1850, the Catholic presence was limited to fourteen locations, most of which were situated along the coast (Algeria, Egypt, Gabon, Natal, and Cape Colony) or on the islands (Madagascar, Mauritius, the Comoros, and the Réunion). There were only two Catholic initiatives in the interior during this time: in Ethiopia (established in 1836 and 1846) and Sudan (established in 1846). In the early part of the nineteenth century, the French journal Annales de l'Association de la propagation de la foi had sections containing extensive reports from Catholic missions in Asia and the Americas, but it reported literally nothing from Africa. A Catholic desire to penetrate the interior of Africa was itself aroused at least in part by increased Protestant missionary activity. ${ }^{2}$

In the period under consideration, Protestant churches and individuals took the lead in preaching the Gospel to native Africans in the interior. Dr. Johannes Theodorus van der Kemp (1747-1811), commonly referred to as Doctor Vanderkemp, ${ }^{3}$ was one of the first three pioneers of the London Missionary Society (LMS) in southern Africa. He reached the Khoikhoi and the Xhosa in that region and even learned their languages. Moffat, who was a close follower of Vanderkemp, worked mainly among the Tswana people, translating the New Testament into their language. These Protestant missionaries had a free field without Catholic competition, and they thus made little or no reference to the Catholics. In the dedication of his book to His Royal Highness Francis Albert Augustus Charles Emmanuel, duke of Saxe (1819-61), Moffat praised the house of Saxony for standing by Martin Luther (1483-1546), whom he acknowledged as "the great Reformer," and for offering him protection "against the power of

2 Ronald Werner, William Anderson, and Andrew Wheeler, Day of Devastation, Day of Contentment: The History of the Sudanese Church across 2000 Years (Nairobi: Paulines Publications Africa, 2000), 131 .

3 See A.D. [Arthur David] Martin, Doctor Vanderkemp (London: Livingstone Press, 1931). 
Rome." ${ }^{4}$ This is the only reference that gives an indication of Moffat's view of Catholicism as a threat. However, rather than being incidental to Moffat's account, the reference to "the power of Rome" and the implied need to combat it belonged to a larger narrative that became more pronounced in the second half of the nineteenth century.

An article by one "K," published in the July 1886 issue of the Protestant journal The Church Missionary Intelligencer and Record, bore the title "On the Character of Jesuit Missionary Teaching." It offered a Protestant assessment of the Jesuits, not only in Africa but throughout the order's history. Regularly referring to the Catholic Church as the "Romish Church," the article is not strictly representative of Protestant opinion at the time but it certainly serves to highlight some extreme Protestant views about Catholics and, more specifically, the Jesuits. The Catholic missionary record in Africa, as in other places, appears rather pitiable in the article. Speaking about Catholic missions that had "long since melted away like foam upon the waters," whose very existence "is unknown, except to curious inquirers into the records of the past," the article mentions Africa as a place that "teems with instances of such desolation, among what are said once to have been flourishing Romish Missions." But even here, the article says, "there has been a complete and utter disappearance of them; they have passed away, and have not left a wrack behind to intimate that they once had a being." Despite such a critical view, the article delicately combines praise to Catholic authorities for dealing firmly with the Jesuits with acknowledgment of Jesuit missionary achievement in previous centuries: "Rome would show badly, notwithstanding her early start in the field, if it had not been for the Jesuit body": 5

The all-important question, however, for consideration in a periodical like ours is not what was the skill or success of the Jesuits as explorers, or rulers, or scientific teachers, or even promoters of civilization among wild and barbarous tribes, but what was the nature and character of their teaching as professed ministers and evangelists of Christianity. The utmost that their friends and admirers might wish to claim for them might be readily conceded in many secular matters, and yet there might be a woful [sic] defect in the substance of their spiritual teaching and their method of communicating it, which would make them hinderers rather than promoters of the Gospel. As extremes not unfrequently [sic] meet, it

4 Robert Moffat, Missionary Labours and Scenes in Southern Africa (London:John Snow, 1842), i.

5 K., "On the Character of Jesuit Missionary Teaching," Church Missionary Intelligencer and Record (July 1886): 529-44, here 530. 
might be that a cold, calculating political economist like John Stuart Mill could perceive in Jesuit operations concerning temporal matters what he could largely approve of, and yet that if their proceedings were weighed in the balances of the sanctuary they might be found to be of little or no value at all. ${ }^{6}$

A key line of argument in this quotation is that, even if Jesuits were successful in social and economic areas of the secular order of things, such success could not make up for their failure to pass on the Christian faith to people in mission territories. Although a generalization, this assessment is critically important in Africa, where the Catholic faith the Jesuits preached and its public manifestation in practice had largely vanished from the regions that Livingstone visited in the middle of the nineteenth century.

\section{Livingstone on Jesuit Missionary Economics in Africa}

A Scotsman, Livingstone trained as a medical doctor, eventually becoming an anti-slavery campaigner, a Christian missionary, an explorer, and a British consul. As a missionary, his eyes were first fixed on China. He turned to Africa only after the Opium Wars (1839-42 and 1856-6o) had denied him access to the country of his first missionary dream. It is said that, as a scientist and believer, he "saw no conflict between faith and scientific understanding." His "Christianity had a strong practical bent" and his faith made him devote his "life to the alleviation of misery." Livingstone's rich background made him view his missionary activity in the broadest terms possible, thereby avoiding the secular-religious dichotomy that is apparent in the extreme position outlined above. In a speech delivered in Senate House, Cambridge, in 1857, he said, "I might have gone on instructing the natives in religion, but as civilization and Christianity must go on together, I was obliged to find a path to the sea, in order that I should not sink to the level of the natives." ${ }^{8} \mathrm{He}$ firmly believed

6 Ibid., 535 .

7 Willie Henderson, "Livingstone, David," in Dictionary of African Biography, ed. Emmanuel K. Akyeampong and Henry Louis Gates Jr., 6 vols. (Oxford: Oxford University Press, 2012), 3: 510-12, here 510; see David Livingstone, Missionary Travels and Researches in South Africa: Including a Sketch of Sixteen Years' Residence in the Interior of Africa (London: Ward, Lock \& Co., 1857), 4.

8 David Livingstone, David Livingstone and Cambridge: A Record of Three Meetings in the Senate House (London: Universities Mission to Central Africa, 1908), 9. 
in the triad of civilization, commerce, and Christianity and worked tirelessly to introduce the three into Africa. In fact, for Livingstone, civilization (meaning "European civilization") was the ultimate goal, one that was midwifed by Christianity and commerce: "Those two pioneers of civilization-Christianity and commerce-should ever be inseparable; and Englishmen should be warned by the fruits of neglecting that principle as exemplified in the result of the management of Indian affairs,"9 he said.

Given his broad disposition, the great missionary was well positioned to look at the Jesuits more favorably than some of his fellow missionaries, admiring them for their achievements in commerce and education and recommending them for Protestant imitation, even as he mourned their dismal performance in religion. He carefully observed Jesuit markings in south central Africa and missed no opportunity to mention them in his letters, speeches, and writings. He took note of nearly any mention of the Jesuits in south central Africa on any topic, however unsubstantiated the claims made about them appeared to be.

In an 1860 letter to Admiral Sir Frederick William Grey, K.C.B. (1805-78), Livingstone mentioned the doubtful existence of a silver mine "said to have been worked by the Jesuits of old," which some members of his expedition were working tirelessly to rediscover..$^{10}$ There is hardly any mention of Jesuitowned silver mines or any silver mines at all in other sources related to the sixteenth- and seventeenth-century missions in the region. Elsewhere, Livingstone attributed the introduction of coffee and species of fruits and trees to Angola that he considered useful for timber to the Jesuits and other missionaries. ${ }^{11}$ In his estimation, mangoes, oranges, cashews, and other farm produce were "all fruits of the Jesuits' labour."12 The link between Jesuits and coffee, like that with silver mines, is somewhat problematic too. More recent authors date the introduction of the crop to Angola in the $1830{ }^{13}{ }^{13}$ yet, after their expulsion in 1759 , Jesuits did not return to the country until 1967.

$9 \quad$ Ibid., 13.

10 Wallis, Zambezi Expedition, 1: 157.

11 Livingstone, Missionary Travels, 346.

12 Isaac Schapera, ed., David Livingstone: Family Letters 1841-1856, 2 vols. (London: Chatto \& Windus, 1959), 2: 277.

13 See Bayetta Bellachew, "A Brief Account of Coffee Production in Angola: A Quick Assessment," Travel Report no. 11, Inter Africa Coffee Organization \& African Coffee Research Network (June 2015), 1, available online at http://www.iaco-oiac.org/sites/default/files/ travel_report_no_11_-_angola_o.pdf (accessed May 29, 2017); Yonah Seleti, "Finance Capital and the Coffee Industry of Angola 1867-1895," Transafrican Journal of History 16 (1987): 63-77, here 63 . 
Livingstone was more accurate when it came to the other things he attributed to the Jesuits. While exploring the vast territory that constitutes Congo and Angola today, he counted more than twelve abandoned churches, which he believed had belonged to the Capuchins and the Jesuits. It is quite possible that Livingstone would have seen the church of Our Lady of Victory at Masanganu near Dondo, built by Paulo Dias de Novais $(c .1510-89),{ }^{14}$ the first Portuguese governor whom the Jesuits accompanied to Angola. He certainly saw the Church of Jesus and the College of Jesus in Luanda, the undisputed seventeenth-century Jesuit monuments in that city. ${ }^{15}$

Similarly accurate was Livingstone's observation of the fruits of Jesuit labor in African education. When he visited the former site of the missionary station of Cahenda, located about twelve miles north of Ambaca, he was pleasantly surprised by "the great numbers who can read and write." This he attributed to the Capuchins and the Jesuits, and the fact that fond memories of the Jesuits still existed in the place would seem to confirm his conclusions. "Ever since the expulsion of the teachers by the Marquis of Pombal," he noted, "the natives have continued to teach each other."16 Manifesting deliberate focus on a subject of great personal interest and introducing a comparison that betrays his preference for Jesuits, Livingstone dwelled on this observation in an 1854 letter to his brother Charles Livingstone (1821-73):

I have been examining some of the old Jesuit Mission stations in the country, and the fruits of their labours. From all accounts the Jesuits were very exemplary in their lives, and devoted themselves to the instruction of the people conscientiously. The effect of their efforts is seen in the numbers who can read \& write in the country. They teach each other now, and in the district of Ambaca it is considered a disgrace for any one to be unable to read. When the Jesuits were expelled from Portuguese territory by the Marquis of Pombal, the place of the Jesuits was supplied by a batch of the regular priesthood, with fine long beards. These were graceless bardies, who loved to tuck up their habits and join in the dances of the Natives [...]. The people could tell nothing about these last batch except their fine beards. ${ }^{17}$

14 See Emanuel Cabaco et al., As Igrejas monumentos de Angola: Exposição fotográfica (Luanda: Festival Nacional de Cultura de Angola and Instituto Nacional do Património Cultural, 2014), 51-53.

15 Livingstone, Livingstone and Cambridge, 23; see Cabaco et al, Igrejas monumentos, 74-77.

16 Livingstone, Missionary Travels, 330.

17 Schapera, David Livingstone, 2: 255 . 
In sharp contrast, Livingstone reported in an 1856 letter to his father-in-law that there were no similar remains of Jesuit teaching in Mozambique. ${ }^{18}$

Besides their reported success in education, Jesuits also scored high on trade and, more generally, on organizational style. It is worth reemphasizing here that Livingstone appears to praise in the Jesuits what he himself wished to promote. For Livingstone, commerce was a path to "civilization," and anything he might learn from the Jesuits in this regard was likely to advance his own course. Moreover, like many other missionaries of his time, Livingstone was financially under-supported. He betrayed a degree of frustration with Christians in Britain who considered their donations to support missionaries as "charity" rather than as their share of a common obligation to "go into all the world and preach the gospel to every creature." 19 In fact, at some point the LMS viewed his activities to be connected "only remotely with the spread of the gospel" and thus felt unable to continue aiding his plans financially, forcing him to consider accepting a government-sponsored consular position. ${ }^{20}$ At this point, Livingstone became-as one author describes him - "more of a public scientist than a gospel evangelist."21 It was within this context of limited resources for mission that he argued for the need to combine missionary work and trade in the same person, saying that such a combination

would not be morally wrong, for nothing would be more fair, and apostolical too, than that the man who devotes his time to the spiritual welfare of a people should derive temporal advantage from upright commerce, which traders, who aim exclusively at their own enrichment, modestly imagine ought to be left to them. ${ }^{22}$

To this end, therefore, Livingstone was willing to cross all denominational boundaries to learn from previous missionary experiences. "In the early ages the monasteries were the schools of Europe," he said, "and monks were not ashamed to hold the plough."23 The Dutch clergy, who were "not wanting in worldly wisdom," were a model to emulate too. With them,

18 Ibid., 2: 284 .

19 Livingstone, Missionary Travels, 30; also see Livingstone, Livingstone and Cambridge, 26.

20 Wallis, Zambezi Expedition, 1: xvi, xx, xxii-xxiv.

21 Shanet Clark, "Dr. David Livingstone: Cultural Approaches to an Important Victorian Figure," Education Forum, 2005, available online at http://educationforum.ipbhost.com/ index.php?/topic/3895-dr-david-livingstone/ (accessed May 29, 2017).

22 Livingstone, Missionary Travels, 29.

23 Livingstone, Livingstone and Cambridge, 14. 
a fountain is bought, and the lands which it can irrigate parcelled out and let to villagers. As they increase in numbers the rents rise and the church becomes rich. With £20o per annum in addition from Government, the salary amounts to $£ 400$ or $£ 500$ a year. The clergymen then preach abstinence from politics as a Christian duty. It is quite clear that, with $£_{400}$ a year, but little else except pure spirituality is required. ${ }^{24}$

The admired monks were in Europe, and we are not sure where the Dutch clergy were, although they could have been in South Africa at that time. It is clear, however, that the Jesuits in south central Africa were the model missionary-traders in the imagination of Livingstone; in fact, the example of the Dutch clergy was just an illustrative footnote after a lengthy description of the Jesuits. Probably not without exaggeration, Livingstone said:

The Jesuits, in Africa at least, were wiser in their generation than we; theirs were large influential communities, proceeding on the system of turning the abilities of every brother into that channel in which he was most likely to excel; one, fond of natural history, was allowed to follow his bent; another, fond of literature, found pleasure in pursuing his studies; and he who was great in barter was sent in search of ivory and gold-dust; so that while in the course of performing the religious acts of his mission to distant tribes he found the means of aiding effectively the brethren whom he had left at the central settlement. We Protestants, with the comfortable conviction of superiority, have sent out missionaries with a bare subsistence only, and are unsparing in our laudations of some for not being worldly-minded whom our niggardliness made to live as did the prodigal son. ${ }^{25}$

In a similar vein, Livingstone was inclined to give a positive assessment of Jesuit work in Mozambique, even though he admitted that their performance there could not match up to that in Angola. Describing a former Jesuit settlement he saw about ten miles southeast of Tete, he confessed to have observed that "both judgment and taste had been employed in the selection of the site," as indeed "in all their settlements." Here, "a little stream of mineral water had been collected in a tank and conducted to their house, before which was a little garden for raising vegetables at times of the year when no rain falls." Like their brethren in Angola, Jesuits in Mozambique are described as great traders:

24 Livingstone, Missionary Travels, $29 n 1$.

25 Ibid., 29. 
"Large quantities of gold had often been sent to their superiors in Goa," said Livingstone, adding that the Jesuits "were keen traders in ivory and gold dust" and that "all praise their industry" because "whatever they did, they did it with all their might." Speaking about their expulsion from Mozambique, which happened in 1759, Livingstone mourned "the riches of the fraternity, which were immense." As these were confiscated by the state, Livingstone concluded that "probably their [Jesuits'] successful labours in securing the chief part of the trade to themselves had excited the envy of the laity."26

When the Jesuits did not own the praised farms themselves, Livingstone attributed to them the wisdom that influenced their choice of location. Talking about one such farm at Zumbo in today's Mozambique, he said: "The early traders, guided probably by Jesuit missionaries, must have been men of taste and sagacity." Like the Jesuits, they too

selected for their village the most charmingly picturesque site in the country, and had reason to hope that it would soon be enriched by the lucrative trade rivers Zambesi and Luangwa pouring into it from the north and the west, and by the gold and ivory of the Manica country on the south. ${ }^{27}$

It is now known for certain that the Jesuits owned huge tracts of land in Mozambique. They may also have been traders as described, even though the degree of their economic success is open to question. As Jesuit historian William Francis Rea (1908-80) later demonstrated, the Jesuit missions in Mozambique were economically stressed and stood little chance of success even if the expulsion had not happened in $1759 .{ }^{28}$ However, this should not distract us from Livingstone's key point about the economics of missionary survival, in which he believed Jesuits excelled. From this viewpoint, Livingstone would not endorse the summary assertions of the mid-seventeenthcentury Angolan political class that "the fathers had deserted God in favour of Mammon."29 Nor would he have been privy to the late nineteenth-century

\footnotetext{
$26 \quad$ Ibid., 551.

27 David Livingstone and Charles Livingstone, Narrative of an Expedition to the Zambesi and Its Tributaries; And of the Discovery of the Lakes Shirwa and Nyassa, 1858-1864 (London: John Murray, 1865), 203.

28 William Francis Rea, The Economics of the Zambezi Missions 1580-1759 (Rome: IHSI, 1976), 171.

29 Dauril Alden, The Making of an Enterprise: The Society of Jesus in Portugal, Its Empire, and Beyond, 1540-1750 (Stanford: Stanford University Press, 1996), 217.
} 
opinion, cited previously, that Jesuit operations in temporal matters could be admired only by "a cold, calculating political economist like John Stuart Mill" and were "of little or no value at all" in the balances of the sanctuary. ${ }^{30}$ For Livingstone, commerce, Christianity, and civilization were too intricately connected to allow for such a clear-cut distinction between the sacred and the secular, and, in the context of meagre resources from Christians in Europe to missions in Africa, missionaries had better lived with the wisdom of serpents even as they pursued the innocence of doves. In his view, the Jesuits in Africa did just that.

\section{Livingstone on the Jesuit Christian Legacy in Africa}

While he approved of Jesuit missionary methods in Africa, Livingstone brooded over Christianity's almost complete disappearance from the lands they had evangelized for so many years. His description of this missionary failure as observed in one location in Mozambique is sobering:

The chapel, near which lies a broken church bell, commands a glorious view of the two noble rivers [...]. It is an utter ruin now, and desolation broods around [...]. The foul hyena has defiled the sanctuary, and the midnight-owl has perched on its crumbling walls to disgorge the undigested remnant of its prey. One can scarcely look without feelings of sadness on the utter desolation of a place where men have met to worship the Supreme Being, or have united in uttering the magnificent words, "Thou art the King of glory O Christ!" and remember, that the natives of this part know nothing of His religion, not even His name; a strange superstition makes them shun this sacred place, as men do the pestilence, and they never come near it. Apart from the ruins, there is nothing to remind one that a Christian power ever had traders here; for the natives of to-day are precisely what their fathers were, when the Portuguese first rounded the Cape. Their language, unless buried in the Vatican, is still unwritten. ${ }^{31}$

For Livingstone, the Jesuit failure to pass on a kind of faith that could propagate itself was seriously disturbing. While they preserved so many other Jesuit relics, native Africans had held tenaciously to their ancestral religion as though

30 K., "Character of Jesuit Teaching," 530.

31 Livingstone and Livingstone, Narrative of Expedition, 204. 
they had never encountered Christianity. Livingstone could observe that Africans had "a clear idea of a Supreme Being, the maker and governor of all things," that they "promptly acknowledge him as the ruler over all," and that they "also fully believe in the soul's continued existence apart from the body."32 However, in his estimation, the practical expression of that faith showed no link to earlier contacts with Christianity: "They pray to their departed relatives, by whom they imagine illnesses are sent to punish them for any neglect on their part";33 "When they escape, or recover from sickness, or are delivered from any danger, they offer a sacrifice of a fowl, or a sheep, pouring out the blood as a libation to the soul of some departed relative"; 34 "They believe in the transmigration of souls; and also that while persons are still living they may enter into lions and alligators, and then return again to their own bodies." ${ }^{35}$ From these observations, it became obvious to Livingstone that the natives who had encountered the Jesuits in south central Africa were at least non-Christians if not raw heathens.

Livingstone was thus confronted with a serious question about what exactly went wrong with the missionary predecessors he so much admired. "Since the early missionaries were not wanting in either wisdom or enterprise," he mused, "it would be interesting to know the exact cause of their failing to perpetuate their faith." ${ }^{36}$ And, indeed, if the Ambacans could pass on the skill of reading and writing from one generation to another long after their teachers had been sent away, could they not have done the same with the faith of their evangelizers? To satisfy himself, Livingstone attempted a two-point response.

In the first part of his response, Livingstone judged that failure to pass the Christian scriptures on to native converts could have undermined the work of the Jesuits. Addressing them as "these our Roman Catholic fellow-Christians," Livingstone argued that the Jesuits and the other Catholic missionaries in south central Africa had kept the Bible to themselves, leaving their converts with nothing that could have become "a light to their feet when the good men themselves were gone. ${ }^{37}$ Indeed, there are records of catechisms and prayerbooks authored or translated by Jesuits in seventeenth-century south central Africa, ${ }^{38}$ but there is no evidence of a Jesuit attempt to render the scriptures

32 Livingstone, Missionary Travels, 550.

33 Livingstone, Livingstone and Cambridge, 12.

34 Livingstone, Missionary Travels, 550.

35 Ibid.

36 Livingstone and Livingstone, Narrative of Expedition, 204.

37 Livingstone, Missionary Travels, 330.

38 In Angola, Mateus Cardoso (1584-1625) translated the Cartilla de la sagrada doctrina into Kikongo in 1624, and a catechism by António do Couto (d. 1666) was published in 
accessible to native Africans in their own languages during this period. Elsewhere, Livingstone noted that the only books native Africans possessed were "histories of saints, and miracles effected by the parings of saintly toe-nails, and such like nonsense."39 Reading this line, one cannot help seeing a connection to broader Protestant opinion, especially with John Calvin's (1509-64) Treatise on Relics (1543) in which Calvin considered it a well-known fact "that the most part of the relics which are displayed everywhere are false, and have been put forward by impostors who have most impudently deceived the poor world."40 Nevertheless, Livingstone would further argue that, "if such an impression has once been produced, it might be hoped that the efforts of other missionaries, who would leave the Bible with these poor people, would not be less abiding." ${ }^{41}$

Generally lauded as even-handed on denominational matters, ${ }^{42}$ Livingstone betrays a view about the effectiveness of the Bible as a tool for evangelization that brings out the Protestant in him and probably manifests a clear Protestant-Catholic distinction in his thinking. In this, he would have been informed by the sola scriptura considerations that had characterized interdenominational debates since the Diet of Worms in $15^{21 .} .^{43}$ More immediately, Livingstone had observed and commented positively on the modest missionary successes of Moffat, his father-in-law, among the Tswana after he had translated the scriptures into their language. ${ }^{44}$ He viewed Moffat's translation as "a great work and likely to be of permanent benefit to the people." ${ }^{45} \mathrm{He}$ also cited Madagascar as an example of a place where the Bible had helped Christianity endure in difficult circumstances. There, he said,

Kimbundu in 1642, whereas in Mozambique Livingstone learned that Jesuits had translated prayers into local languages. See Livingstone, Missionary Travels, 551, and José Vaz de Carvalho, "Angola," in Diccionario histórico de la Compañía de Jesús: Biográfico-temático, ed. Charles E. O'Neill and Joaquín M. Domínguez, 4 vols. (Roma: IHSI, 2001), 1: 171-5, here 174 .

39 Livingstone, Livingstone and Cambridge, 12.

40 John Calvin, A Treatise on Relics, trans. Valerian Krasinski, 2nd ed. (Edinburgh: Johnstone, Hunter \& Co., 1870), 165 .

41 Livingstone, Livingstone and Cambridge, 12.

42 Henderson, “Livingstone," 510.

43 See Georges Tavard, Protestantism, trans. Rachel Attwater (New York: Hawthorn Books, 1959), 19-31. Sola scriptura, Latin for "by scripture alone," refers to the theological position that Christian scriptures alone are the infallible rule of faith and practice, which was at the center of the Catholic-Protestant disagreements following the sixteenth-century Reformation.

44 See Livingstone, Livingstone and Cambridge, 17.

45 Schapera, David Livingstone, 2: 120. 
a few Christians were left with nothing but the Bible in their hands; and though exposed to persecution, and even death itself, as the penalty of adherence to their profession, they increased tenfold in numbers, and are, if possible, more decided believers now than they were when, by an edict of the queen of that island, the missionaries ceased their teaching. ${ }^{46}$

Clearly, Livingstone viewed the Bible as key to any missionary success, and to the extent that the Jesuits failed to pass it on to native Africans, their missionary admirer could not recommend them for Protestant imitation.

Even then, Livingstone's tone remains sympathetic to the Jesuits. Despite the failures he attributed to them, they still remained "our Roman Catholic fellow-Christians," not the "Janissaries of the Church of Rome" that " $\mathrm{K}$ " had contemplated them to be. ${ }^{47}$ This is probably because Livingstone himself, while holding to a properly Protestant view, harbored doubts about the Bible's own power to impart self-perpetuating faith. It would appear that his hope for biblical efficacy was pegged on the consideration that the scriptures, now introduced by Protestants, would create at least as much of a lasting impression as the stories of saints and relics, left behind by Jesuits, had created in African minds. Moreover, even as he praised Moffat's translation of the Bible, he was honest enough to admit that other factors might determine whether or not its impact would last. The Tswana could cease to exist as a people, for example, or their language could simply die out. To Moffat, Livingstone wrote:

Pity your Bible was not translated into negro language, the population is so large and fond of learning. They are an indistructible [sic] race, and, no mistake, they are very prolific. I have had doubts as to the imperishability of the Bechuanas. The Makololo are fast dying out, they don't bring forth like the negroes. The Bakwains are ridiculously impotent. Several other considerations make me fear for their permanence, and with that fear the apprehension that your noble work of translation may come to the same end with Elliot's Choctaw Bible, which lies on a shelf in one of the American colleges, a monument of devotedness an[d] zeal in a language which no living jaws can articulate nor mortal understand. If such a sad consummation should ensue, and I confess I have serious fears that the present Colonial policy tends to accomplish it, your labour of love will

46 Livingstone, Missionary Travels, 102.

47 K., "Character of Jesuit Teaching," 544. "K" uses this term as he compares the Jesuits with Turkish Janissaries, who constituted a highly disciplined elite royal force in the Ottoman Empire and lasted from the fourteenth to the nineteenth century. 
be none the less appreciated by Him who placed you where you are, and whose smile of "Well done" will soothe the soul to everlasting peace. ${ }^{48}$

John Eliot (1604-90) translated the Bible into the language of the now extinct Massachusetts Indians that lived around Boston (though not Choctaw, as Livingstone thought), which is utterly unusable except for archival display. ${ }^{49}$ Yet, missionary labor like that of Eliot, even when it does not produce tangible earthly fruit in the form of lasting conversions, remains a labor of love worthy of eternal reward. Here lies Livingstone's missionary pragmatism, which would not allow him to throw too heavy a blow on the Jesuits.

The second part of Livingstone's response to his own question focused on the slave trade, a practice he considered alien to Africa. Livingstone had no doubt whatsoever that trade in humans was an evil introduced to Africa by the Portuguese, which then hindered the implantation of Christianity on the continent. If all the progeny of the whites were to leave Africa, he said, "their only memorial would be the ruins of a few stone and mud-built walls, and that blighted relic of the slave-trade, the belief which is not of native origin, for it is not found except in the track of the Portuguese. ${ }^{50} \mathrm{He}$ was further convinced that the operations of those systems that sanctioned slavery, be they of native or European origin, only perpetuated "barbarism,"51 which must be contrasted to the "civilization" that Livingstone himself so intricately linked to Christianity and to what later became known as legitimate commerce. ${ }^{52}$

In Livingstone's view, the Jesuits, as indeed all early missionaries in south central Africa, were too enmeshed in the systems that sanctioned the trade in humans for their faith to be taken seriously by the natives they sought to convert. He first proposed this conclusion in the form of a question: "Can it be that the Missionaries of old, like many good men formerly among ourselves, tolerated this system of slave-making, which inevitably leads to warfare, and thus failed to obtain influence over the natives by not introducing another policy than that which had prevailed for ages before they came?"53 He quickly followed this tentative position with the more affirmative statement that a

48 Schapera, David Livingstone, 2: 263; also see Livingstone, Livingstone and Cambridge, 15.

49 Schapera, David Livingstone, 2: $263 n 7$.

50 Livingstone and Livingstone, Narrative of an Expedition, 204; also see Wallis, Zambezi Expedition, 1: xiv.

$5^{1} \quad$ Livingstone and Livingstone, Narrative of Expedition, 204.

$5^{2}$ See Livingstone, Livingstone and Cambridge, 12-13, 23-26; also see Robin Law, ed., From Slave Trade to Legitimate Commerce: The Commercial Transition in Nineteenth-Century West Africa (Cambridge: Cambridge University Press, 1995).

Livingstone and Livingstone, Narrative of Expedition, 205. 
palpable anti-slavery character among native Africans excited such universal attention that "any Missionary, who winked at the gigantic evils involved in the slave-trade, would certainly fail to produce any good impression on the native mind." 54

In south central Africa, the Jesuits did more than wink at slavery and the slave trade together with their menacing consequences for native African populations. In Mozambique, they owned no fewer than seventeen big estates or prazos that were worked by an equally large number of slaves. ${ }^{55}$ It was mainly what remained of these estates that gave Livingstone an impression of "the riches of the fraternity, which were immense. ${ }^{56}$ In Angola, the Portuguese colonial structure, imposed and sustained by force, existed with tacit Jesuit approval. As mentioned earlier, Dias de Novais, the founding Portuguese governor of Angola whose full title came to be "Governor and Commander-in-Chief, Founder and Conqueror of the Kingdom of Sebaste in the Conquest of Ethiopia of Lower Guinea," enjoyed the counsel of the Jesuits, even though evidence of friction and outright disagreement appears between the religious men and their political patrons in later years. ${ }^{57}$ In the end, Angola as a Portuguese colony became what scholars have described as a "slave hunting-ground" 58 and "the largest slave port in Africa." ${ }^{59}$ Others have interpreted the Jesuit role in this development differently, with some assigning them a considerably more influential position. Historian and travel-writer Frederick Clement Christie Egerton, for example, viewed Jesuits as "missionaries of a sterner type, more austere living, and perhaps of a more decided purpose than the easy-going and tolerant clergy who had gone to Congo," and therefore probably "less subject to illusions about the motives which led ambitious native leaders to express interest in Christianity." He further contended that at some point Dias de Novais hoped to attain his ends in Angola by peaceful means, but the Jesuits who advised him "thought otherwise, and they were right." 60 John Thornton,

$54 \quad$ Ibid., 206.

55 See William Francis Rea, "Agony on the Zambezi: The First Christian Mission to Southern Africa and Its Failure, 1580-1759," Zambezia 1, no. 2 (1970): 46-53, here 50; Malyn D.D. Newitt, Portuguese Settlement on the Zambesi (London: Longman, 1973), 89.

56 Livingstone, Missionary Travels, 551.

57 See Alden, Making of an Enterprise, 216-18.

58 John Baur, 2000 Years of Christianity in Africa: An African Church History, 2nd ed. (Nairobi: Paulines Publications Africa, 2009), 73 .

59 James Duffy, Portugal in Africa (Harmondsworth: Penguin, 1962), 59.

6 F. [Frederick] Clement C. Egerton, Angola in Perspective: Endeavour and Achievement in Portuguese West Africa (London: Routledge \& Kegan Paul, 1957), 44; also see Alden, Making of an Enterprise, ${ }^{-7}-76$. 
a prominent historian on the Kingdom of Kongo, has also confirmed that "the Jesuits were fierce advocates of war against the Mbundu to convert them by force," adding that "their lengthy correspondence reads as much like the chronicle of conquest as the report of missionary activities." ${ }^{1}$ Whatever their role in the enterprise, the Jesuits suffered the negative consequences of the brutal colonial conquest of Angola and of the slave-trading empire that stood upon its native societal ruins, giving some credence to the link Livingstone remarked upon between the infamous trade in humans and the dismal Christian gains that he observed.

It is important again to emphasize Livingstone's obviously tentative tone in this verdict. Even as he remained critical, he still understood that Jesuits tolerated trade as a way of making slaves "like many good men formerly among ourselves." That he talked of a "system of slave-making" as opposed to slavery in general is intriguing. It can be said with certainty that Livingstone's stand against the slave trade was absolute, and his desire to see its ending was immediate. However, his views about slavery were probably not as clear-cut. Statements like "By trading with Africa also, we should at length be independent of slave-labour, and thus discountenance practices so obnoxious to every Englishman" betray a degree of lenience, a certain hope that the practice would die out but gradually. Judging him to be "a facts man" who was realistic enough to put up with something that worked even if only with tolerable hardships, colonial administrator and author Philip Birkinshaw (1922-2014) observed in Livingstone "a surprising residue of sympathy for what one might call (by a stretch of imagination) 'decent' slavery and slave-trading." Not that Livingstone found anything to justify slavery, let alone slave-trading, but that "his emotions did not simply rush ahead of the evidence but rather accompanied it, finding the whole business at first distressing and in the end, diabolic." ${ }^{2}$ The Jesuits in south central Africa belonged to a certain age, and Livingstone seems to have judged them within their own context.

\section{Livingstone's Own Legacy}

Despite his indubitable feats, Livingstone's ambitious program for Africa was largely unfulfilled at the time of his death, making him more of a sower of seeds that others would reap than one who sat to enjoy the fruit of his

61 John K. Thornton, "Conquest and Theology: The Jesuits in Angola, 1548-1650," Journal of Jesuit Studies 1, no. 1 (2014): 245-59, here 257.

62 Philip Birkinshaw, The Livingstone Touch (London: Macdonald, 1973), 123, see also 126. 
own labor. Though he remained determined and optimistic to the very end, "Livingstone must have felt that he had failed," says historian Jack Simmons, not least because the slave trade still ravaged east Africa in $1873 .{ }^{63}$ Because of the seeds he had sown, however, this shameful trade was brought to a complete end in 1897 when the institution of slavery was altogether abolished after Zanzibar had become a British protectorate. Moreover, more than anything else, it is as a Christian missionary that Livingstone's legacy must be viewed. Yet, even from this aspect of his career, results were hard to come by. There is only one recorded convert baptized by Livingstone: namely Sechele I (c. 1810-92), chief of the Bakwena in today's Botswana, who later broke the missionary's heart by relapsing. But, again, if Sechele's baptism was a Christian seed, then it is one that grew to bear much fruit on its own. Despite occasional failures in practice (which came down to having intercourse with wives he had renounced at baptism), ${ }^{64}$ Sechele has been judged to have "spread Christianity more effectively than the dour Scotsman ever did."65 Indeed, Livingstone himself recorded that Sechele had "made himself the missionary to his own people." 66

With only one recorded convert to write home about, Livingstone's most important legacy in Africa, like that of the Jesuits before him, could not be in the form of Christian faith imparted to multitudes of native Africans. With years, the legacy scales tilted decidedly in favor of commerce. While the ethnographic and geographical information he generated about Africa's interior was meant to open up the continent for Christianity, commerce, and civilization, he had no control over the manner in which his successors would put it into use. The now familiar charge, that Christianity pacified Africans and European civilization alienated them from their native cosmology and so exposed them to exploitation via imperial commerce, would have shocked Livingstone. Yet seeds of that development can be traced back to him and to other contemporary missionaries and explorers. Arguing that some missionaries never actually bothered to work for conversion, historian Denis Judd says "Livingstone, arguably the most famous of them all, was far more effective as a de facto agent of the Royal Geographical Society, and hence of imperial expansion, than as a

\footnotetext{
63 Jack Simmons, Livingstone and Africa (London: English Universities Press, 1955), 153.

64 See Tim Jeal, Livingstone (London: Pimlico, 1993), 81-82.

65 Erin Rushing, "David Livingstone and the Other Slave Trade, Part I," Smithsonian Libraries, 2013, available online at https://blog.library.si.edu/2013/og/david-livingstone-and-the -other-slave-trade-part-i/\#.WCm98fl95PY (accessed May 29, 2017); also see Fred Morton, "Sechele I," in Dictionary of African Biography, 5: 318-19. 
saver of African souls." ${ }^{67}$ The founders of the African Lakes Company claimed to have started their business in central Africa "in response to the call of David Livingstone, who declared that two conditions were essential for the abolition of the terrible slave trade in the Dark Continent-Christianity and legitimate commerce." ${ }^{68}$ Although generations set them apart, Livingstone and Cecil Rhodes (1853-1902) have also been somewhat connected. Rhodes's territorial imagination in central Africa was informed by Livingstone's "discoveries." As he negotiated for boundaries, he was careful to exploit the sentimental interest of the British people in the Stevenson road connecting Lakes Tanganyika and Malawi because of its association with Livingstone, as well as the tree near Lake Bangweulu, where the missionary died ${ }^{69}$ It becomes obvious, therefore, that by "exploring and, by extension, [...] claiming south central Africa for his native Britain, Livingstone's legacy becomes entwined with that of Cecil Rhodes."70 Some authors have gone further to establish a parallel at least in character between Livingstone and Britain's most accomplished imperialist in Africa: peerless leadership, secluded, inspiring, and hardworking. ${ }^{71}$ Church authorities, politicians, and servants of empire have linked the two by "a combined memorial to these two famous men, in the fulfilment of whose ideals lies the best hope for the future of British Central Africa." ${ }^{72}$

It would be harsh to conclude that Livingstone was a great promoter of trade but a failed Christian missionary. To look at his missionary career differently, we might re-evaluate the very standard against which he judged the Jesuits. It is quite possible that the Jesuits had greater success than Livingstone was actually disposed to seeing. In an article on Christianity in the Kongo Kingdom, Thornton makes a distinction between exclusive and inclusive concepts of Christianity, which might help us see the point. Whereas exclusive Christianity, such as was applied in the Spanish colonies in the Americas, required converts to abandon their own cosmology in order to receive new faith as it were on a clean slate, inclusive Christianity, as was applied in Kongo, was

67 Denis Judd, Empire: The British Imperial Experience from 1765 to the Present (London: HarperCollins, 1996), 88.

68 Fred L.M. Moir, After Livingstone: An African Trade Romance (London: Hodder and Stoughton, 1924), 1. The author is one of two brothers who founded the company in 1877 .

69 See Basil Williams, Cecil Rhodes (London: Constable, 1938), 166-67.

$70 \quad$ Clark, "David Livingstone."

71 Wallis, Zambezi Expedition, 1: xi-xii.

72 From a communication signed by the archbishops of Canterbury and York, the secretary of state for the colonies, Lord Lugard, Lord Hailey, and others, appealing for funds to establish a Rhodes-Livingstone Institute of Central African Studies, published in African Affairs 36, no. 145 (1939): 531-32. 
syncretistic in the positive sense of implanting itself into a native cosmology, with local populations determining the terms of its assimilation. ${ }^{73}$ In the latter manner, Thornton argues, "Christianity conquered Kongo peacefully—but at the cost of adapting itself almost wholly to the 'conquered' people's conception of religion and cosmology."74 Even if to a lesser degree, this conclusion could be extended to other parts of south central Africa that were evangelized by the Jesuits. Livingstone himself noted that "the natives are not absolutely anxious to receive the Gospel, [but] they are open to Christian influences."75 As mentioned earlier, he actually observed elements of Christianity that native Africans had chosen to preserve, including histories of saints and relics, but, bearing a more exclusive concept of the faith, he would not acknowledge them to be validly Christian and, hence, religious legacies left behind by the Jesuits. As Thornton would argue, the apparent disappearance of Christianity from south central Africa in the nineteenth century, which Livingstone lamented, was not due to a lack of conversions of native Africans, a resurgence of their suppressed religion, or a failure on the part of those who preached the Gospel to them; rather, "it was caused by a changing definition among European clergy (including Rome) as to what constituted Christianity, coupled with more chauvinistic attitudes towards non-Western (and especially colonial) peoples that arose after $1850 .{ }^{.76}$ With his own exclusive concept of Protestant Christianity shrouded in an essentially European civilization that he also sought to promote, Livingstone could hardly recognize elements of inclusive Catholic Christianity that were sustained in African cosmology, let alone see a Christian in Sechele who kept his "dismissed" wives company beyond his own baptism.

\section{Bibliography}

Alden, Dauril. The Making of an Enterprise: The Society of Jesus in Portugal, Its Empire, and Beyond, 1540-1750. Stanford: Stanford University Press, 1996.

Baur, John. 2000 Years of Christianity in Africa: An African Church History. 2nd ed. Nairobi: Paulines Publications Africa, 2009.

73 See John Thornton, "The Development of an African Catholic Church in the Kingdom of Kongo, 1491-1750," Journal of African History 25, no. 2 (1984): 147-67, here 152; see also Thornton, "Conquest and Theology," 246. In the latter article, the author speaks about "open" and "closed" versions of Christianity rather than "inclusive" and "exclusive" concepts of Christianity.

74 Thornton, "Catholic Church in Kongo," 154.

75 Livingstone, Livingstone and Cambridge, 14.

76 Thornton, “Catholic Church in Kongo," 148. 
Bellachew, Bayetta. "A Brief Account of Coffee Production in Angola: A Quick Assessment." Travel Report no. 11, Inter Africa Coffee Organization \& African Coffee Research Network (June 2015). http://www.iaco-oiac.org/sites/default/files/travel_ report_no_11_-_angola_o.pdf (accessed May 29, 2017).

Birkinshaw, Philip. The Livingstone Touch. London: Macdonald, 1973.

Cabaco, Emanuel et al. As Igrejas monumentos de Angola: Exposição fotográfica. Luanda: Festival Nacional de Cultura de Angola and Instituto Nacional do Património Cultural, 2014.

Calvin, John. A Treatise on Relics. Translated by Valerian Krasinski. 2nd ed. Edinburgh: Johnstone, Hunter \& Co., 1870.

Clark, Shanet. "Dr. David Livingstone: Cultural Approaches to an Important Victorian Figure.” Education Forum, 2005. http://educationforum.ipbhost.com/index.php?/ topic/3895-dr-david-livingstone/ (accessed May 29, 2017).

Duffy, James. Portugal in Africa. Harmondsworth: Penguin, 1962.

Egerton, F. [Frederick] Clement C. Angola in Perspective: Endeavour and Achievement in Portuguese West Africa. London: Routledge \& Kegan Paul, 1957.

Henderson, Willie. "Livingstone, David." In Dictionary of African Biography, edited by Emmanuel K. Akyeampong and Henry Louis Gates Jr., 3: 510-12. 6 vols. Oxford: Oxford University Press, 2012.

Jeal, Tim. Livingstone. London: Pimlico, 1993.

Judd, Denis. Empire: The British Imperial Experience from 1765 to the Present. London: HarperCollins, 1996.

K. "On the Character of Jesuit Missionary Teaching." Church Missionary Intelligencer and Record (July 1886): 529-44.

Law, Robin, ed. From Slave Trade to Legitimate Commerce: The Commercial Transition in Nineteenth-Century West Africa. Cambridge: Cambridge University Press, 1995.

Livingstone, David. David Livingstone and Cambridge: A Record of Three Meetings in the Senate House. London: Universities Mission to Central Africa, 1908.

Livingstone, David. Missionary Travels and Researches in South Africa: Including a Sketch of Sixteen Years' Residence in the Interior of Africa. London: Ward, Lock \& Co., 1857 .

Livingstone, David, and Charles Livingstone. Narrative of an Expedition to the Zambesi and Its Tributaries; And of the Discovery of the Lakes Shirwa and Nyassa, 1858-1864. London: John Murray, 1865.

Martin, A.D. [Arthur David]. Doctor Vanderkemp. London: Livingstone Press, 1931.

Moffat, Robert. Missionary Labours and Scenes in Southern Africa. London: John Snow, 1842.

Moir, Fred L.M. After Livingstone: An African Trade Romance. London: Hodder and Stoughton, 1924.

Newitt, Malyn D.D. Portuguese Settlement on the Zambesi. London: Longman, 1973. 
Rea, William Francis. "Agony on the Zambezi: The First Christian Mission to Southern Africa and Its Failure, 1580-1759." Zambezia 1, no. 2 (1970): 46-53.

Rea, William Francis. The Economics of the Zambezi Missions 1580-1759. Rome: IHSI, 1976.

Rushing, Erin. "David Livingstone and the Other Slave Trade, Part I." Smithsonian Libraries, 2013. https://blog.library.si.edu/2013/og/david-livingstone-and-the-other -slave-trade-part-i/\#.WCm98fl95PY (accessed May 29, 2017).

Schapera, Isaac, ed. David Livingstone: Family Letters 1841-1856. 2 vols. London: Chatto \& Windus, 1959.

Seleti, Yonah. "Finance Capital and the Coffee Industry of Angola 1867-1895." Transafrican Journal of History 16 (1987): 63-77.

Simmons, Jack. Livingstone and Africa. London: English Universities Press, 1955.

Tavard, Georges. Protestantism. Translated by Rachel Attwater. New York: Hawthorn Books, 1959.

Thornton, John K. "Conquest and Theology: The Jesuits in Angola, 1548-1650." Journal of Jesuit Studies 1, no. 1 (2014): 245-59.

Thornton, John K. "The Development of an African Catholic Church in the Kingdom of Kongo, 1491-1750." Journal of African History 25, no. 2 (1984): 147-67.

Wallis, J.P.R. [John Peter Richard], ed. The Zambezi Expedition of David Livingstone 1858-1863. 2 vols. London: Chatto \& Windus, 1956.

Werner, Ronald, William Anderson, and Andrew Wheeler. Day of Devastation, Day of Contentment: The History of the Sudanese Church across 2000 Years. Nairobi: Paulines Publications Africa, 2000.

Williams, Basil. Cecil Rhodes. London: Constable, 1938. 